\title{
Correlation and Path Coefficient Analysis in Segregating Population of Upland Cotton (Gossypium hirsutum L.)
}

\author{
Vrinda Joshi* and B.R. Patil \\ Department of Genetics and Plant Breeding, College of Agriculture, UAS, \\ Dharwad-580005, Karnataka, India \\ *Corresponding author
}

\section{A B S T R A C T}

\section{Keywords}

Correlation, Path coefficient Gossypium hirsutum

Article Info

Accepted:

04 July 2018

Available Online:

10 August 2018
In the present investigation the boll weight followed by number of bolls per plant, boll weight and number of sympodia per plant were positively associated with seed cotton yield per plant in the $F_{2}$ populations. Plant height, number of monopodia per plant, number of sympodia per plant, ginning outturn, seed index, fibre strength and maturity ratio exhibited positive direct effect on seed cotton yield per while, lint index, upper half mean length, uniformity ratio and micronair exhibited negative direct effect. Number of bolls per plant had positive indirect effect on seed cotton yield per plant via number of sympodia per plant, seed index, lint index, fibre strength etc. Boll weight was responsible for high yield through seed index, ginning outturn, lint index. The information obtained helps in giving proper weightage to the various characters during selection or other breeding programme so that the improvement of desirable traits can be achieved effectively.

\section{Introduction}

Upland Cotton (Gossypium hirsutum L.) is a predominant species of cotton cultivated mainly for its lint in more than 80 countries of world. Selection based on multiple traits is always better than selection based on yield alone. Since yield is a quantitative character controlled by many genes, an adequate knowledge about the magnitude and degree of association of yield with its attributing characters is of great significance to the breeders, through which they can clearly understand the strength of correlated traits, when they have to exercise selection for simultaneous improvement of more than one character. However, correlation alone does not provide information on the contribution of 
related characters, which necessitates the study of cause and effect relationship of different characters among themselves. Therefore, the path analysis depicts the exact relationship of characters there by providing more information than correlation.

\section{Materials and Methods}

Phenotypic correlations were worked out in $\mathrm{F}_{2}$ population of RHAP-12 X RHAP-7 to determine the degree of association of a character with yield and also among the yield components using the formula given by Weber and Moorthy (1952). Estimated correlation coefficients were compared against $r$ values given in Fisher and Yates (1963) table at (n 2) degrees of freedom at the probability levels of 0.05 to test their significance. Path coefficient analysis was carried out for all the traits to know the direct and indirect effects on yield as suggested by Wright (1921) and illustrated by Dewey and Lu (1959).

\section{Results and Discussion}

Phenotypic correlation and path coefficients for yield, yield attributing and fibre quality traits of cotton are presented in Table 1 and 2. Seed cotton yield is most important trait with respect to farmer point of view and improvement of this trait will improve the economy of cotton growing farmers.

Association between contributing traits like plant height, monopodia per plant, sympodia per plant, number of bolls per plant, boll weight, lint index, lint yield per plant, boll recorded and seed cotton yield positive significant association with (Farooq et al., 2014 and Ramesh 2015).

In the present study significant positive association with seed cotton yield was observed for boll weight followed by number of bolls per plant, boll weight and number of sympodia per plant. Therefore, selecting high yielding plants based on, number of bolls per plant, boll weight and number of sympodia per plant will be more useful. In Merchant's point of view ginning outturn is very important because it shows the recovery of lint from seed cotton. Present study recorded significant positive association with lint index (lint obtained from 100 seeds) and upper half mean length. Similar results also reported by Ramesh (2015). Vinodhana et al., (2013) reported the seed index, lint index and ginning outturn had significantly positive correlation with seed cotton yield.

Textile industry point of view fibre quality is most important, because it decides the garments quality. In the study of Vinodhana et al., (2013), Erande et al., (2014) and Ramesh (2015) positive significant association between fibre strength and length was reported but, significant negative association with micronair value. In the present study negative correlation was observed for elongation ratio and micronair whereas, it exhibited positive correlation with strength to length ratio.

Plant height, number of monopodia per plant, number of sympodia per plant, ginning outturn, seed index, fibre strength and maturity ratio exhibited positive direct effect on seed cotton yield per plant indicating effectiveness of direct selection for these traits while, lint index, upper half mean length, uniformity ratio and micronair exhibited negative direct effect. Number of bolls per plant had positive effect on seed cotton yield per plant via number of sympodia per plant, seed index, lint index, fibre strength etc. Boll weight was responsible for high yield through seed index, ginning outturn, lint index. Similar results were observed by Salahuddin et al., (2010), Reddy et al., (2015). Low residual effect indicated that the selection of traits for path coefficient analysis is appropriate and none of the character was neglected. 
Table.1 Association among yield, yield attributing and fibre quality traits in $\mathrm{F}_{2}$ population of cross RAHP 12 X RAHP 7

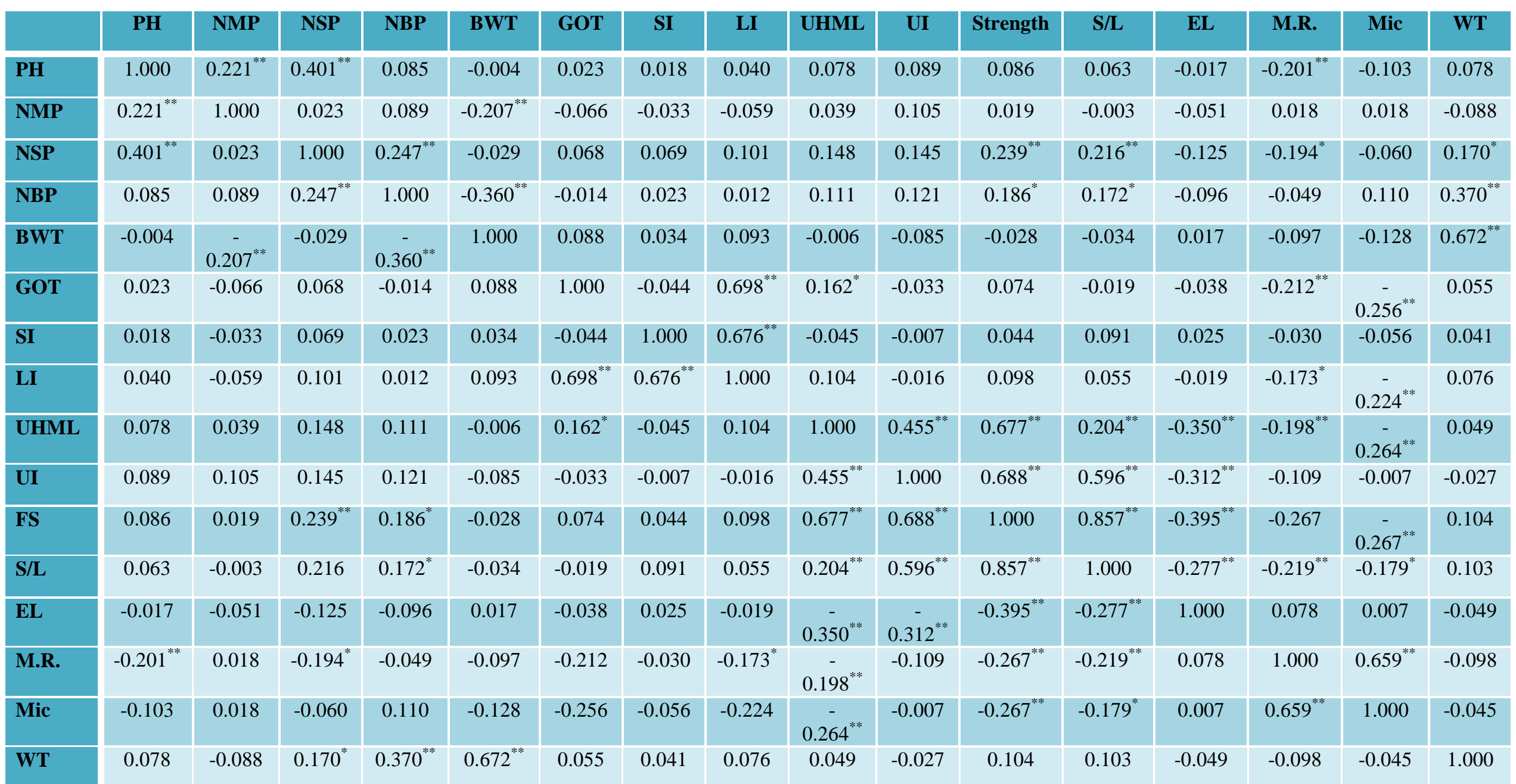

Where, PH-Plant Height (cm), NMP- Number of Monopodia per Plant, NSP- Number of Sympodia per Plant, NBP- Number of Bolls per Plant, BWG- Boll Weight in Grams, GOT- Gining outturn in percent, SI- Seed Index, LI- Lint Index, SCYP- Seed Cotton Yield per Plant in grams, UHML- Upper Half Mean Length, FUR- Fiber Uniformity Ratio, FS- Fiber Strength, S/L- Strength over the Length ratio, FEL-Fiber Elongation in percent, MR- Maturity Ratio, MICMicronair value in $\mu \mathrm{g} / \mathrm{inch}$. 
Table.2 Direct and indirect effect of yield, yield attributing and fibre quality traits in $\mathrm{F}_{2}$ population of cross RAHP 12 X RAHP 7

\begin{tabular}{|c|c|c|c|c|c|c|c|c|c|c|c|c|c|c|c|c|}
\hline & PH & NMP & NSP & NBP & BWT & GOT & SI & LI & UHML & UI & Strength & $\mathrm{S} / \mathrm{L}$ & EL & M.R. & Mic & WT \\
\hline PH & 0.0158 & 0.0035 & 0.0064 & 0.0013 & -0.0001 & 0.0004 & 0.0003 & 0.0006 & 0.0012 & 0.0014 & 0.0014 & 0.0010 & -0.0003 & -0.0032 & -0.0016 & 0.0784 \\
\hline NMP & 0.0102 & 0.0461 & 0.0010 & 0.0041 & -0.0095 & -0.0030 & -0.0015 & -0.0027 & 0.0018 & 0.0048 & 0.0009 & -0.0002 & -0.0023 & 0.0008 & 0.0008 & -0.0878 \\
\hline NSP & 0.0108 & 0.0006 & 0.0269 & 0.0066 & -0.0008 & 0.0018 & 0.0019 & 0.0027 & 0.0040 & 0.0039 & 0.0064 & 0.0059 & -0.0034 & -0.0052 & -0.0016 & $0.1705 * *$ \\
\hline NBP & 0.0595 & 0.0624 & 0.1734 & 0.7028 & -0.2534 & -0.0100 & 0.0159 & 0.0085 & 0.0783 & 0.0848 & 0.1308 & 0.1244 & -0.0674 & -0.0342 & 0.0770 & $0.3703 * *$ \\
\hline BWT & $\begin{array}{c}- \\
0.0039\end{array}$ & -0.1930 & -0.0274 & -0.3371 & 0.9350 & 0.0822 & 0.0318 & 0.0864 & -0.0059 & -0.0799 & -0.0260 & -0.0358 & 0.0161 & -0.0912 & -0.1200 & $0.6718 * *$ \\
\hline GOT & 0.0028 & -0.0082 & 0.0085 & -0.0018 & 0.0109 & 0.1241 & -0.0055 & 0.0866 & 0.0201 & -0.0041 & 0.0092 & -0.0028 & -0.0047 & -0.0263 & -0.0318 & 0.0546 \\
\hline SI & 0.0022 & -0.0041 & 0.0085 & 0.0028 & 0.0042 & -0.0054 & 0.1223 & 0.0827 & -0.0056 & -0.0009 & 0.0054 & 0.0113 & 0.0031 & -0.0036 & -0.0068 & 0.0412 \\
\hline LI & $\begin{array}{c}- \\
0.0077\end{array}$ & 0.0112 & -0.0193 & -0.0023 & -0.0177 & -0.1337 & -0.1296 & -0.1917 & -0.0201 & 0.0029 & -0.0189 & -0.0104 & 0.0037 & 0.0332 & 0.0430 & 0.0751 \\
\hline UHML & $\begin{array}{c}- \\
0.0094\end{array}$ & -0.0046 & -0.0177 & -0.0133 & 0.0007 & -0.0194 & 0.0054 & -0.0126 & -0.1195 & -0.0544 & -0.0809 & -0.0245 & 0.0418 & 0.0237 & 0.0316 & 0.0491 \\
\hline UI & $\begin{array}{c}- \\
0.0059\end{array}$ & -0.0069 & -0.0096 & -0.0080 & 0.0057 & 0.0022 & 0.0005 & 0.0010 & -0.0302 & -0.0664 & -0.0457 & -0.0398 & 0.0207 & 0.0073 & 0.0004 & -0.0272 \\
\hline Strength & 0.0188 & 0.0042 & 0.0523 & 0.0408 & -0.0061 & 0.0162 & 0.0096 & 0.0216 & 0.1483 & 0.1507 & 0.2190 & 0.1876 & -0.0865 & -0.0584 & -0.0585 & 0.1037 \\
\hline $\mathrm{S} / \mathrm{L}$ & $\begin{array}{c}- \\
0.0067\end{array}$ & 0.0004 & -0.0237 & -0.0192 & 0.0042 & 0.0024 & -0.0101 & -0.0059 & -0.0222 & -0.0651 & -0.0931 & -0.1087 & 0.0302 & 0.0237 & 0.0189 & 0.1025 \\
\hline EL & 0.0001 & 0.0002 & 0.0005 & 0.0004 & -0.0001 & 0.0001 & -0.0001 & 0.0001 & 0.0013 & 0.0012 & 0.0015 & 0.0011 & -0.0038 & -0.0003 & 0.0000 & -0.0485 \\
\hline M.R. & $\begin{array}{c}- \\
0.0118\end{array}$ & 0.0010 & -0.0114 & -0.0029 & -0.0057 & -0.0124 & -0.0017 & -0.0102 & -0.0116 & -0.0064 & -0.0156 & -0.0128 & 0.0046 & 0.0587 & 0.0387 & -0.0981 \\
\hline Mic & 0.0036 & -0.0006 & 0.0021 & -0.0038 & 0.0045 & 0.0090 & 0.0019 & 0.0079 & 0.0093 & 0.0002 & 0.0094 & 0.0061 & -0.0003 & -0.0231 & -0.0350 & -0.0451 \\
\hline
\end{tabular}

Where, PH-Plant Height (cm), NMP- Number of Monopodia per Plant, NSP- Number of Sympodia per Plant, NBP- Number of Bolls per Plant, BWG- Boll Weight in Grams, GOT- Gining outturn in percent, SI- Seed Index, LI- Lint Index, SCYP- Seed Cotton Yield per Plant in grams, UHML- Upper Half Mean Length, FUR- Fiber Uniformity Ratio, FS- Fiber Strength, S/L- Strength over the Length ratio, FEL-Fiber Elongation in percent, MR- Maturity Ratio, MICMicronair value in $\mu \mathrm{g} / \mathrm{inch}$.

Residual effect $=0.3302$ 


\section{References}

Dewey DR and Lu KN. A correlation and path coefficient analysis of components of crested wheat grass seed production. Agron. J. 1959; 51: 515-518.

Erande, C. S., Kalpande, H. V., Doesarkar, D. B., Chavan, S. K., Patil, V. S., Deshmukh, J. D., Chinchane, V. N., Kumar, A., Dey, U. and Puttawar, M. R. 2014, Genetic variability, correlation and path analysis among different traits in desi cotton (Gossypium arboreum L.) African J. Biotech., 29: 2278-2286.

Farooq, J., Anwar, M., Riaz, M., Farooq, A., Mahmood, A., Shahid, M. T. H., Rafiq, M. and Ilahi, F., 2014. Correlation and path coefficient analysis of earliness, fibre quality and yield contributing traits in cotton (Gossypium hirsutum L.). J. Animal Pl. Sci., 24(3): 781-790.

Fisher RA and Yates F. Statistical Tables for Biological, Agric. and Medical Research. ( $6^{\text {th }} E d$.) Longman Group Ltd, Harlow. 1963, 63-64.

Ramesh, 2015, genome mapping and identification of molecular markers for various agronomic and fibre quality traits in tetraploid cotton. Ph. D. Thesis, Univ. Agric. Sci, Dharwad, Karnataka (India).

Reddy, K. B., Reddy, V. C., Ahmed, M. L., Naidu T. C. M. and Srinivasarao, V., 2015, Correlation and path coefficient analysis in upland cotton (Gossypium hirsutum L.) Int. J. Pure App. Biosci. 3 (3): 70-80.

Salahuddin, S., Abro, S. and Kandhro, Salahuddin, M. M. and Laghari, S., 2010, correlation and path coefficient analysis of yield components of upland cotton (Gossypium hirsutum L.) Sympodial. World Appl. Sci. J., 8: 7175.

Vinodhana, N. K., Gunasekaran, M. and Vindhiyanvarman, P., 2013, Genetic studies of variability, correlation and path coefficient analysis in cotton genotypes. Int. J. Pure Appl. Biosci., 1(5): 6-10.

Weber and Moorthy BR. Heritable and nonheritable relationship and variability of oil content and agronomic characteristics in the $F_{2}$ generation of soybean crosses. Agron. J. 1952; 44: 202-209.

\section{How to cite this article:}

Vrinda Joshi and Patil, B.R. 2018. Correlation and Path Coefficient Analysis in Segregating Population of Upland Cotton (Gossypium hirsutum L.). Int.J.Curr.Microbiol.App.Sci. 7(08): 125-129. doi: https://doi.org/10.20546/ijcmas.2018.708.015 